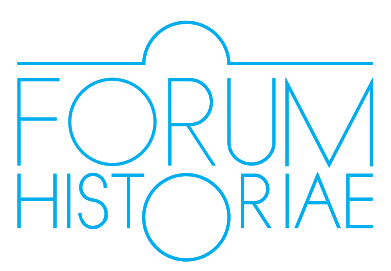

\title{
„Odt’até ruky“? \\ Kontinuity a diskontinuity politických \\ a spoločenských elít na Slovensku v 19. a 20. storočí
}

\author{
Peter Šoltés - László Vörös
}

\begin{abstract}
ŠOLTÉS Peter - VÖRÖS László: „Hands Severed“? Continuity and Discontinuity of Political and Social Elites in Slovakia in the 19th and 20th Centuries.

The article is an introduction to the current issue of Forum Historiae that was supported by the Slovak Research and Development Agency project "Continuity and Discontinuity of Political and Social Elites in Slovakia in the 19th and 20th Centuries". The editors provide a brief overview of the theoretical concepts that underlie the articles published in the issue; they introduce the main research questions and hypotheses the authors of the issue worked with and outline the main conclusions.
\end{abstract}

Keywords: power elites, social elites, Austria-Hungary, Czechoslovakia, 1918

$\mathrm{T}$ ento rok si pripomíname výročie viacerých významných udalostí 19. a 20. storočia. Osmičkový rok tentoraz rezonuje o čosi viac, ked'že uplynie sto rokov od založenia Československa a polstoročie od okupácie Československa armádami Varšavskej zmluvy. Oslavy výročí, štátom organizované festivity a iné formy kultúry spomínania by prinajmenšom z odborného diskurzu nemal zatlačit’ do úzadia úvahy nad dôsledkami závažných vnútropolitických a medzinárodných kríz, zmeny režimov a politicko-ekonomických systémov.

Tradičný pohl’ad na zmeny režimov vychádza z tézy o hlbokých politických ruptúrach, ktoré so sebou prinášali rozsiahle zmeny rozloženia moci. Ich sprievodným znakom boli personálne, kultúrne a sociálne diskontinuity, ktoré radikálne zmenili dovtedajší vývoj spoločnosti. Historik L'ubomír Lipták v roku 1990 publikoval inšpiratívnu úvahu, v ktorej hladal odpoved’ na otázku, či bolo Slovensko skutočne krajinou generácií „s odt’atými rukami““1 Podl’a Liptáka boli slovenské dejiny v 19. a 20. storočí poznačené zmenami režimov a diskontinuitami: nové pokolenia prichádzali, chopili sa práce, získali postavenie, budovali kariéry, ale ešte než sa mohli plne rozvinút', boli v dôsledku politických a spoločenských zmien odstavené a nahradené novými elitami. Aktuálne číslo Forum Historiae je jedným z výstupov vedeckého projektu Kontinuity a diskontinuity politických a spoločenských elít na Slovensku v 19. a 20. storočí, medzi ktorého výskumné ciele patrilo i overenie platnosti tézy o „odtatých rukách“, ale i d’alších dlhodobo akceptovaných presvedčení, ktorých platnost' doteraz nebola overená empirickým výskumom a konkrétnymi analýzami.

* Toto číslo Forum Historiae bolo podporené Agentúrou na podporu výskumu a vývoja na základe zmluvy č. APVV-14-0644 Kontinuity a diskontinuity politických a spoločenských elít na Slovensku v 19. a 20. storočí.

1 LIPTÁK, L'ubomír. Storočie dlhšie ako sto rokov. Bratislava : Kalligram, 2011, s. 133-138. 
Po roku 1918 sa v dovtedy bezprecedentnom počte súčast'ou mocenských, funkčných aj spoločenských elít stali jednotlivci z neelitných vrstiev - jav, ktorý z kvantitatívneho hladiska prekonala len radikálna reorganizácia politického a hospodárskeho systému po roku 1948. V celom procese ustanovenia nových elít na Slovensku po roku 1918 je nesmierne dôležitý faktor importovaných elít z Čiech a Moravy. V podmienkach novo vzniknutej Československej republiky sa nanovo ustanovili mad’arské a nemecké politické strany, v rámci ktorých sa profilovali aj osobnosti, ktoré vo vztaha k svojej menšinovej komunite tvorili elitu, vo vzt’ahu k československej mocenskej štruktúre však predstavovali potenciálnu kontraelitu. Z hladiska témy projektu - kontinuity a diskontinuity elít - je obdobie dezintegrácie Rakúsko-Uhorska a vzniku Československa a prvých rokov ustanovenia jeho politických, výkonno-mocenských a správnych štruktúr priam vzorovým prípadom, na ktorom možno skúmat' takmer všetky aspekty vzniku, fungovania a obnovovania elít. Podobne významnou, ak nie ešte významnejšou periódou je aj predĺžené desat'ročie medzi rokmi 1937/1938 - 1948/1949, na ktorej príklade možno skúmat’ kontinuity a diskontinuity, stratégie sebazáchovy a „regrutovania“ nových elít v kontextoch závažných vnútropolitických a medzinárodných kríz, piatich režimov a troch politicko-ekonomických systémov - pluralitného demokratického (ČSR 1918 - 1938 a ČSR 1945 - 1948), autoritatívneho (ČSR 1938 - 1939 a autonómna Slovenská krajina 1938 - 1939), totalitárneho (Slovenský štát/republika 1939 - 1945 a ČSR po roku 1948). Jedným z výskumných zámerov riešitelov projektu bolo sledovanie prípadných režimových špecifík alebo práve, naopak, podobností pri postupoch integrácie a vylúčenia starých elít, miery personálnej kontinuity na jednotlivých úrovniach výkonu moci a správy.

Z hladiska skúmania stratégií „pretrvania“ starých elít v podmienkach nových režimov je dôležité venovat’ pozornost' sociálnym faktorom kontinuity, t. j. udržaniu v pozícii elity i v podmienkach nového režimu. Riešitelia projektu sa zamerali na skúmanie sociálneho pozadia a sociálnych väzieb úspešných jednotlivcov. V prípade niektorých typov elít - najmä funkčných a na lokálnej úrovni - sa ukázalo, že významným determinantom boli rodinné, komunitné a regionálne vztảahy, resp. identifikačné rámce a na nich založené postoje lojality. V prípade mocenských elít na strednej a najmä vyššej úrovni ostáva miera dôležitosti spomenutých tradičných väzieb otvorenou otázkou.

Jeden z klasických teoretikov elít Vilfredo Pareto vo svojej teórii o cirkulácii elít postuluje, že viac-menej úplná výmena elít je pravidelným cyklickým procesom. Elity ako indivíduá s najvyššou vecnou kompetenciou sa prirodzene obmieňajú, obvykle na základe meritokratického princípu medzi seba vpúšt’ajú nadaných jednotlivcov z radov „neelít“ (t. j. z más bežného obyvatel'stva), ktorých jednak asimilujú do svojho hodnotového systému a jednak ich pripravia na výkon moci. Súčast’ou takejto reprodukcie elít je aj vytesňovanie menej zdatných jednotlivcov z druhej či tretej generácie na perifériu (obvykle títo sú cielene nahradzovaní z radov neelít). Ked' sa tento reprodukčný a samoočistný mechanizmus naruší, napríklad vnútroskupinovým favoritizmom, klientelizmom a nepotizmom, meritokratický princíp prestane fungovat' ako reprodukčné kritérium, dochádza k úpadku a náhlemu revolučnému nahradeniu starých 
elít novými z radov neelitného obyvatel'stva. Pareto teda hovorí, že v pravidelných cykloch dochádza k jednoznačnej diskontinuite a úplnej výmene (cirkulácii) mocenských elít. ${ }^{2}$ Spomínaná Paretova teória síce neberie dostatočne do úvahy také faktory ako mocenský zásah „spoza hraníc“ alebo vel'ké geopolitické zmeny, má však i napriek tomu určitý, nie zanedbatel'ný explanačný potenciál. Domnievame sa však, že pokial' ide o klúčové prelomové obdobia slovenských dejín v 20. storočí, pri ktorých došlo k ustanoveniu nových štátnych útvarov a teritoriálnym zmenám, resp. zmenám politických a ekonomických režimov, nie je potvrditelná. Naopak, v súlade so základnou hypotézou riešitelov projektu, podla ktorej okrem diskontinuít existovali aj kontinuity elít, dokonca aj pri tých najradikálnejších režimových premenách, je teoretická koncepcia Roberta Michelsa „železného zákona oligarchie“. Podl’a Michelsa každá organizácia - či už politická strana alebo iná - sa nevyhnutne vyvinie na oligarchickú, teda ovládanú málopočetnými silnými záujmovými skupinami a/alebo rodinami či rodmi bez ohladu na jej ideologické pozadie. Teda nielen v organizáciách fungujúcich na základe princípov autoritatívneho riadenia - napr. v stranách krajnej pravice či l'avice, ale aj v takých organizáciách, ktoré deklarujú uplatňovanie pluralitných a meritokratických zásad - napr. občianskych či sociálnodemokratických stranách, sa skôr či neskôr presadí úzky okruh vedúcich osobností, ktorých primárnym ciel’om sa stane zachovanie a reprodukcia svojho postavenia a moci v rámci organizácie.

Michels však súhlasí s Paretom, že základným mechanizmom reprodukcie elít je zlučovanie predstavitelov starých elít s novými nositel'mi elitného statusu bud' spomedzi už v iných oblastiach a kontextoch etablovaných skupín, alebo priamo z neelitného obyvatel'stva. Tento proces nazýva permanentnou amalgamizáciou elít. Podl'a Michelsa však nemožno ešte ani pri najdôslednejších revolučných zmenách hovorit’ o úplnej výmene elít. Možno hovorit' len o rôznych pomeroch, v ktorých dochádza k amalgamizácii starých a nových elít. Čast’ pôvodnej „panujúcej triedy“ sa vždy „prenesie“ do nového režimu a adaptuje sa na nové podmienky, pričom si uchová svoj status mocenskej elity. ${ }^{3}$

Štúdie Lucie Seglovej, Veroniky Gayer-Szeghy a Attilu Simona publikované v aktuálnom čísle Forum Historiae potvrdzujú platnost' Michelsovho modelu amalgamizácie elít ako dôsledok zmien režimov. V prípade dejín Slovenska i širšieho kontextu dejín strednej a stredovýchodnej Európy nedošlo v období rokov 1938 - 1939, s výnimkou vyšších úrovní výkonnej a zákonodarnej moci, k fundamentálnej diskontinuite vládnucich a nevládnucich (spoločenských) elít. Vo vyššej štátnej správe, štátnych organizáciách a politických zoskupeniach bola personálna kontinuita politických a funkčných elít najslabšia. Na strednej a nižšej úrovni výkonnej moci, v štruktúrach samosprávy, ale najmä v prípade „čerstvo“ sformovaných slovenských funkčných elít bola kontinuita, naopak, vel'mi výrazná. Jedným z vysvetlení je nenahraditel'nost' funkčných elít pre politický systém a štruktúry moci. Tieto segmenty správy spoločnosti sa obvykle

2 PARETO, Vilfredo. The Mind and Society. III. Theory of Derivations. London : Jonathan Cape Thirty Bedford Square, 1935, (§ 2026-2059), s. 1421-1432.

3 MICHELS, Robert. Political Parties. A Sociological Study of the Oligarchical Tendencies of Modern Democracy. New York : Heart's International Library Co., 1915, s. 365-392, 400-404. 
priamo nepodielali na politickej moci, zastávali však nejakú formu vedúcej pozície a pri uplatňovaní moci mali nezastupitel'nú úlohu. Do tejto kategórie patrí vyššie štátne a samosprávne úradníctvo, podnikatel'ské a finančnícke špičky, manažment, členovia dozorných rád v bankách, významných podnikoch, vedúci činitelia bezpečnostných orgánov a ozbrojených síl štátu (polícia, armáda) a pod.

Vládnuce elity sa od obdobia osvietenstva snažili legitimizovat’ svoju moc i participáciou na sociálnej a zdravotníckej starostlivosti. Túto agenda dovtedy vykonávala cirkev prostredníctvom vlastných inštitúcií a štát v dôsledku obmedzovania jej mocenského vplyvu tieto aktivity preberal. Ingrid Kušniráková vo svojej štúdii skúmala prostriedky a metódy, ktorými boli uhorské elity zo strany panovníčky/ka ovplyvňované a usmerňované k tomu, aby i ony na seba prevzali čast' zodpovednosti. Očakávalo sa od nich, že sa budú osobne podiel'at' na zbieraní a prerozdel'ovaní finančných prostriedkov a svojou štedrost’ou pôjdu ostatným príkladom. Kušniráková predstavuje rozsiahle reformné plány Jozefa II. v oblasti chudobinskej starostlivosti a analyzuje príčiny, pre ktoré ich v danom období nebolo možné v uhorských podmienkach realizovat'. V prvej polovici 19. storočia sa však niektoré z jozefínskych princípov začali uskutočňovat’ iniciatívou „zdola“. Dobročinné spolky zakladané a spravované miestnymi elitami sa popri cirkvách, samosprávach a štátnej moci stali najvýznamnejšími subjektmi pôsobiacimi v oblasti chudobinskej starostlivosti. Boli nositelmi modernizačných trendov a prispeli k jej profesionalizácii a špecializácii.

Prípad etablovania nových regionálnych politických elít v dôsledku zmeny režimu a pravidiel získania a reprodukcie politickej moci na štátnej aj regionálnej úrovni skúma vo svojej štúdii József Demmel. Po prijatí tzv. aprílových zákonov uhorským snemom a ich sankcionovaní panovníkom na jar roku 1848 pre čast’ predstavitel’ov slovenského národného hnutia vznikli možnosti etablovania v štruktúrach zákonodarnej a výkonnej moci v stoliciach severozápadného Uhorska. Demmel skúmal dianie v Turčianskej stolici, jeho zistenia sa však rovnako vzt’ahujú aj na d’alšie stolice (Liptovská, Trenčianska, Zvolenská), v ktorých sa o účast' v politickom živote hlásili slovenskí národovci. Na jar a v lete roku 1848 nastala situácia, v ktorej na seba narazili záujmy, programy a ciele konzervatívnej zemianskej stoličnej šlachty, slovenských národovcov a mladej generácie liberálnej stoličnej šlachty, ktorá podporovala reformné hnutie, ktoré na sneme presadzovali Lajos Kossuth a d’alší predstavitelia reformného hnutia. Turčianske konzervatívne zemianstvo, ktoré najlepšie ovládalo slovenčinu a latinčinu, sa cítilo byt' ohrozené vo svojich politických právach a privilégiách predovšetkým dvomi reformami, ktoré presadila reformná liberálna šlachta na Uhorskom sneme: zavedením mad’arčiny ako jediného rokovacieho jazyka stoličných orgánov a zavedením daňovej povinnosti pre šlachtu v Uhorsku. Zavedenie mad’arčiny ako jazyka správy a politického diskurzu významne zvýhodňovalo mladú stoličnú šlachtu, ktorá na rozdiel od generácie svojich otcov a dedov už výborne ovládala mad’arský jazyk. S mad’arčinou ako jediným jazykom výkonu moci nemohli súhlasit' ani slovenské národovecké elity, ked’že išlo o opatrenie, ktoré bolo v príkrom rozpore s ich programom politickej emancipácie Slovákov. Vd’aka tejto súhlasnosti záujmov vzniklo medzi konzervatívnym 
turčianskym zemianstvom a slovenskými národovcami pragmatické spojenectvo, ktoré však nemalo dlhé trvanie. Turčianski zemania sa nedokázali stotožnit’ s národným programom slovenských národovcov, ktorý vnímali ako ohrozujúci územnú celistvost' Uhorského král'ovstva. Politický boj starých a nových elít napokon skončil „amalgamizáciou“ konzervatívnej a liberálnej stoličnej šlachty na úkor slovenských národovcov, ktorí boli koncom 60. a v 70. rokoch 19. storočia úplne vytlačení zo štruktúr zákonodarnej a výkonnej moci Turčianskej stolice.

Matica slovenská združovala v 60. a 70. rokoch 19. storočia podstatnú čast’ slovenskej národoveckej elity. Prekvapivo však doteraz nebola jej členská základňa a ani pomerne obmedzený okruh jej vedúcich predstavitelov (výborníkov) predmetom prozopografickej analýzy. Štúdia Rastislava Moldu je venovaná problematike etablovania slovenských národoveckých elít v tzv. matičných rokoch. V prvej časti identifikuje členskú základňu spolku a jeho volené vedenie, rekonštruuje sociálne a profesijné pozadie výborníkov. Jeho hlavnou výskumnou otázkou je, či národovci združení v Matici samých seba považovali za elitné vrstvy slovenskej spoločnosti. Druhá čast' je venovaná analýze stratégií, ktoré vedenie spolku využívalo na reprodukovanie národoveckých elít, oslovovanie nových generácií. Vel'mi účinným, i ked’ v podmienkach slovenského národného hnutia obmedzeným nástrojom bolo pridelovanie štipendií vybraným študentom. Preferovanie budúcich právnikov bolo motivované snahou o výraznejšie preniknutie medzi lokálnu elitu, najmä do župných úradov a do samosprávy miest. Na základe biogramov matičných štipendistov sa pokúsil odpovedat' na otázku, nakol'ko bola investícia do nich z pohladu rozvoja národného hnutia prospešná.

Ďalšej generácii slovenských národovcov sa vo svojej štúdii venovala Lucia Segl’ová, ktorá skúmala konkrétnu skupinu účastníkov deklaračného zhromaždenia v Turčianskom Sv. Martine (30. októbra 1918). Sledovala kariéry 33 deklarantov, ktorí v čase deklaračného zhromaždenia žili v Turčianskom Sv. Martine. Deklaračné zhromaždenie, na ktorom sa ustanovila Slovenská národná rada a prijala Deklarácia slovenského národa, predstavovalo (a dodnes predstavuje) v kolektívnej pamäti jeden z najdôležitejších politických aktov predstavitel'ov slovenského národného hnutia. Účastníci tohto zhromaždenia už len vd’aka samotnému faktu svojej prítomnosti v nasledujúcich rokoch, ba dokonca desat'ročiach disponovali určitým sociálnym kapitálom. Segl’ová skúmala rodinné pozadie a príbuzenské vzt’ahy jednotlivých martinských deklarantov, pričom sa snažila zistit', či tieto mali vplyv na ich neskoršie úspechy v oblasti ich pôsobenia. Paralelne sledovala aj dosah zmien režimov - v rokoch 1918 (dezintegrácia Rakúsko-Uhorska a vznik Československa), 1938/1939 (dezintegrácia Československa a vznik vojnovej Slovenskej republiky) a 1948 (uchopenie moci Komunistickou stranou Československa) - na kariéry 33 deklarantov.

Slovenské národovecké elity boli z hl'adiska ich sociálneho pôvodu, inštitucionálneho zázemia a celkovo možností spoločenského uplatnenia senzitívnejšie na zmeny politického režimu. Najmä v podmienkach dualizmu bol ich kariérny postup, možnosti realizovat’ sa v akademickom, úradníckom, ekonomickom prostredí limitované ich lojalitou k oficiálnemu štátoprávnemu konceptu Uhorska. Vznik Československej republiky v tomto ohlade predstavoval zásadný 
zlom. Nedostatok elít lojálnych novému štátu sa na Slovensku riešil dvoma spôsobmi. Prvým bol import elít z českých krajín. Podobne ako v 50. rokoch 19. storočia hlboké politické a spoločenské zmeny mali za následok nedostatok lojálnych funkčných elít. Ich absencia paralyzovala upevňovanie moci nového štátu a ako najjednoduchšie a najrýchlejšie riešenie sa javilo importovat' ich z Predlitavska. V medzivojnovom období, najmä v prvých rokoch novej republiky českí profesori, lekári, nižší pedagógovia a vysokí a strední štátni úradníci pôsobiaci na Slovensku kompenzovali deficit tohto typu slovenských elít. Štúdia Anny Falisovej a Vojtecha Ozorovského predstavuje na príklade dvoch výrazných osobností lekárskej vedy (chirurgie) hlavné problémy, ktoré ovplyvňovali konštituovanie tejto disciplíny v podmienkach medzivojnového Československa. Stanislav Kostlivý patril k zakladatel’om slovenskej chirurgie, Konštantín Čársky k prvej generácii slovenských chirurgov. Politické cezúry a akútny nedostatok odborníkov vytvorili predpoklady na ich rýchly kariérny rast - vznik ČSR pre S. Kostlivého a vznik vojnovej Slovenskej republiky pre K. Čárskeho. Zmena režimu po roku 1938 znamenala pre väčšinu českej inteligencie nútený koniec ich pôsobenia na Slovensku. Ako ukazuje príklad S. Kostlivého, ani vysoká odbornost', silný sociálny kapitál vnútri lekárskej komunity nemuseli stačit’ na to, aby odolali politicky a ideologicky motivovaným čistkám. Na druhej strane sa za krátky čas podarilo zakladatel'skej generácii českých lekárov a pedagógov vychovat' silnú generáciu lekárskych špecialistov, ktorí do istej miery zmierňovali dôsledky personálnej diskontinuity spôsobenej zmenami režimu.

Ďalšie tri štúdie publikované v tomto čísle sú chronologicky rámcované dvoma významnými medzníkmi „krátkeho“ 20. storočia (Eric Hobsbawm). Prvý predstavujú politické, ekonomické a sociálne premeny po rozpade Rakúsko-Uhorska a vzniku nástupníckych štátov v období 1918 - 1920. Druhou cezúrou je Viedenská arbitráž a zánik Československa v rokoch 1938/39, ked' sa po tlakom nacistickej zahraničnej politiky zrútil politický systém budovaný za prvej republiky. Československá republika (1918 - 1938/1939), hoci ju jej mocenské elity vyhlasovali za národný štát Čechov a Slovákov, resp. československého národa, bola obývaná aj dvomi početnými etnickými menšinami, ktoré sa považovali za cudzorodý a potenciálne nelojálny element. V slovenskej historiografii sa v diskusiách o vplyve politických cezúr na kontinuity a diskontinuity elít doteraz málo reflektovala otázka územia, ktoré sa v dôsledku Viedenskej arbitráže pričlenilo k Mad’arsku. V Komárne, Rimavskej Sobote, Košiciach, Leviciach a desiatkach d’alších miest pripojených k Mad’arsku došlo k zmenám v zložení lokálnych politických elít.

Štefan Gaučík sa zameral na nesmierne zaujímavý prípad úspešného lučenského menšinového mad’arského podnikatel’a a politického aktivistu Ödöna Tarjána. Paradoxne Tarján napriek diskriminačným krokom zo strany vládnej moci zaznamenal vo svojej podnikatel'skej kariére najväčšie úspechy v prvom desat'ročí existencie Československa. Jedným z predpokladov jeho úspechov boli kontakty na niektorých miestnych slovenských predstavitelov československej štátnej moci, predovšetkým na L’udovíta Bazovského, s ktorým sa poznal ešte z obdobia spred roku 1918. Po niekol'kých zásahoch československých úradov proti jeho osobe a súdnom procese pre podozrenia z korupčných transakcií s L'. Bazovským sa v roku 1933 rozhodol odíst’ 
z Československa a usídlit’ sa v Mad’arsku, kde sa začal postupný prepad jeho kariéry. Zatial' čo v podmienkach Československa bol úspešným podnikatel’om, váženým členom mad’arskej menšinovej komunity a predstavitel'mi menšinovej mad’arskej politickej elity bol považovaný za vplyvného experta na otázky československej národnostnej a hospodárskej politiky, v Mad’arskom královstve sa jeho postavenie zredukovalo len na znalca „československej otázky“, poradcu iredentistických organizácií. Bez majetku a pozície v politických štruktúrach, v prostredí, v ktorom jeho znalosti mali výrazne nižšiu hodnotu, sa postupne dostal na úplnú perifériu politického a spoločenského života.

Mad’arským politickým elitám, konkrétne poslancom a senátorom zastupujúcich mad’arské strany a frakcie v Národnom zhromaždení Československej republiky v období rokov 1920 - 1939, sa vo svojej štúdii venuje Attila Simon. Hoci aktívny profesijný život vel'kej väčšiny poslancov a senátorov začal už v podmienkach Uhorska, takmer bez výnimky sa politickej činnosti začali venovat' až v podmienkach vznikajúcej Československej republiky. Simon pomocou analýzy životopisných dát 39 skúmaných poslancov a senátorov ukázal jednoznačnú personálnu diskontinuitu mad’arských politických elít na území Slovenska v období pred a po roku 1918. Významnejší mad’arskí politickí činitelia krátko po vzniku Československa 28. októbra 1918 bud' opustili územie Slovenska, alebo sa väčšinou z pragmatických dôvodov prestali politicky angažovat'. Nová politická elita mad’arskej menšinovej komunity v Československu sa musela v plnej miere nanovo a náhle ustanovit’ z radov neelitných vrstiev. Podobná situácia úplnej personálnej diskontinuity mad’arskej politickej elity na Slovensku sa druhýkrát objavila v roku 1948, ked’ nové elity opät’ vzišli „živelne“ z vrstiev neelitného obyvatel'stva. V tomto prípade však nešlo o spontánny proces, ale o dôsledne riadený výber uskutočnený predstavitel'mi Komunistickej strany Československa.

Veronika Szeghy-Gayer vo svojej štúdii hl'adá odpoved' na viaceré, doteraz obchádzané otázky. Skúma, akú úlohu zohrala po politickom prevrate v roku 1938 miestna mad'arská elita, aktívna v rokoch v menšinovej politike počas Československa. Aké kritériá museli spíňat' novo dosadení členovia municipálneho výboru v Košiciach a aká politická minulost’ predurčovala či, naopak, diskvalifikovala prípadnú novú politickú elitu mesta. V rozpore s doteraz tradovanými názormi preukázala, že medzi politickou elitou Košíc pred a po roku 1938 existovala značná personálna kontinuita. Vedenie mesta pozostávalo aj po Viedenskej arbitráži z košických osobností pôsobiacich v miestnej politike už niekol'ko desat'ročí. Vyvrátila tak mýtus rozširovaný v dobovej verejnej diskusii a reprodukovaný i v historiografii o silnej pozícii úradníkov a štátnych zamestnancov, ktorí prišli do Košíc z Mad’arska, tzv. „anyásov“. Municipálny výbor Košíc po prvej Viedenskej arbitráži pozostával z osôb, ktoré študovali v čase dualizmu a ktorých prevažná väčšina začínala svoju politickú kariéru v opozícii za trvania Československej republiky. Vel'ká čast' skúmaných poslancov disponovala aspoň desat'ročnou praxou v miestnom politickom živote a vd’aka pozíciám či členstvám v mad’arských politických stranách boli známi aj pre mad’arské vládne kruhy. Municipálny výbor sa v rokoch 1938 - 1945 z národnostného hladiska pretvoril na výhradne mad’arský a neodzrkadloval ani rôznorodost' politického života 
z medzivojnového obdobia. Mimo výboru totiž zostali miestni reprezentanti lavicových hnutí s pomerne vysokou voličskou podporou. Poslanecké miesta vyčlenené pre Slovákov zaujali politici lojálni mad’arskému štátu.

Štúdie, ktoré prináša nové číslo Forum Historiae, ukazujú, aké komplikované a problematické bolo postavenie spoločenských elít v tejto časti Európy v uplynulých dvoch storočiach. V každom režime plnili dôležitú úlohu pri udržiavaní a legitimizácii moci, zároveň však predstavovali rezervoár, z ktorého sa formovala potenciálna kontra-elita usilujúca o reformu či zmenu systému. Bez ohl'adu na demokratické parametre jednotlivých režimov, ktoré sa u nás vystriedali, si každý z nich programovo vytváral vlastné spoločenské elity. Selektoval, kto môže a kto nemôže ašpirovat' na vrcholové pozície a viac či menej úspešne sa snažil usmerňovat' ich výchovu. Tento ambivalentný vzt’ah sa odrážal aj na prístupe spoločenských elít voči existujúcemu režimu. Značná čast’ $\mathrm{z}$ nich bola na režime priamo existenčne závislá a mala záujem na jeho udržaní. Táto závislost' spôsobovala, že spoločenské elity boli náchylné pri radikálnych politických a ideologických zmenách deklarovat' lojalitu tej strane, ktorá uchopila moc. A držitelia moci, uvedomujúc si ich dôležitost' a t’ažkú nahraditel'nost', im prevrátenie kabáta, aspoň na istý čas, zvyčajne prepáčili.

Cituj:

ŠOLTÉS Peter - VÖRÖS László: „Odt’até ruky“? Kontinuity a diskontinuity politických a spoločenských elít na Slovensku v 19. a 20. storočí. In Forum Historiae, 2018, r. 12, č. 1, s. 1-8. ISSN 1337-6861.

$\cdots$

doc. Mgr. Peter Šoltés, PhD.

Oddelenie dejín 19. storočia

Historický ústav SAV,

P. O. Box 198,

Klemensova 19,

81499 Bratislava

Peter.Soltes@savba.sk
Mgr. László Vörös, PhD.

Oddelenie dejín 19. storočia

Historický ústav SAV,

P. O. Box 198,

Klemensova 19,

81499 Bratislava

Ladislav.Voros@savba.sk 